\title{
The EU and national sovereignty: the encounter of two concepts of sovereignty. Change or continuity?
}

\author{
AISTE் DEIMANTAITE் \\ Vytautas Magnus University, Kaunas, Lithuania \\ aiste.deimantaite@gmail.com
}

\begin{abstract}
The article aims to examine and critically evaluate the idea of sovereignty and the nuances of its verbal expression through the concept of strategic narratives, to reveal different models of sovereignty within the context of European Union Member States (mainly France, Hungary/Poland) and the European Union (EU) since 2017. The article seeks to answer the following questions: What idea of sovereignty has been projected to the public in selected European countries and the EU by their political actors since 2017? What model, functional limits and narratives do actors forge?
\end{abstract}

Key words: EU, sovereignty, EU member states, France, Hungary, Poland

\section{Introduction}

The concept of sovereignty is among the most contentious in the political sciences. Its perception depends on the events, circumstances, hopes and ideas of a particular era. For example, in Antiquity, it was perceived as a cosmological order. In the Middle Ages, respublica Christiana, sovereignty was perceived as belonging to God (as a source of authority and power). Later, Jean Bodin's spoke about absolute and perpetual power in which supreme power emanated from a single person or exclusive group of individuals (Bodin, 1992). Later came the Westphalian perception, as well as the imperial and modern(-istic) concepts of sovereignty, the essence of which is territorial definiteness and eurocentrism, which is also when national sovereignty and the sovereignty of the people were conceptualised. As concepts changed gradually, this study is particularly interested in more recent discussions about the concept of EU sovereignty as proposed by French President Emmanuel Macron by outlining "six keys to European sovereignty" in 2017 (Macron, 2017) and based on unified and centralised EU policy in the fields of technology, economy, health, security, climate and others (Leonard \& Shapiro, 2019; 2020).

In the EU's more recent history, the migrant crisis of 2015 stirred debates about the concept of EU and member states' sovereignty. In 2017, French President Emmanuel Macron proposed a new take on EU sovereignty in his speech "Initiative for Europe: A sovereign, united, democratic Europe", and in 2019 the EU developed its strategic sovereignty paper, which was complemented by other documents that were more issuespecific (for example, with a focus on Brexit, the Covid-19 pandemic or relations with the US and China). 
In recent years, political actors have drawn on the concept of sovereignty as a means to drive mechanisms around changing the functions of the EU and decision-making limits, which has also meant that the scope of the concept has expanded into 'sovereignties': economic, health, data, energy, defence, trade and so on. Further, a strategic function of a renewed concept of sovereignty promises a more coherent narrative of Europe and the EU in the world (see Heinrichs in this Special Issue). In theory, all subsets of sovereignty - or what Mark Leonard and Jeremy Shapiro (2019) call "strategies" - should align through one powerful derivative. Further, one of the features of the concept of sovereignty is that others must recognise it. However, who recognises the sovereignty of the EU and who matters in the process of validation or substantiation? Is it the EU's institutions, individual EU member staates, their citizens or other global players?

It follows that the question and varying perceptions of sovereignty are becoming an increasingly difficult, yet important problem for the EU to address. A theoretical model of the concept, presented by some European actors such as Emmanuel Macron, Jean-Claude Juncker (former President of the European Commission) and Josep Borrell (High Representative of European Union) in their public communications, clashes with perceptions and 'alternative narratives' (see Introduction of this Special Issue by Chaban, Heinrichs, Osička and Zapletalová) formulated and projected by some other actors (e.g. far-right movements; see also Popivanov in this Special Issue) that is narratively rooted in the past and tradition.

Moreover, ambiguity and evolution of the concept of sovereignty create new challenges and raise dilemmas around unity, identity and the EU's Self-positioning in the international arena. New challenges are foremostly associated with the surge of far-right movements who criticise the EU's neo-liberal identity and its bureaucratic structure as well as target a more general context of globalisation (see Popivanov, in this Special Issue). In light of these pressures and the geopolitical significance of EU sovereignty, this article examines and critically evaluates the idea of sovereignty and the nuances and strategic functions of its verbal expression through the prism of strategic narratives (Miskimmon, O'Loughlin \& Roselle, 2013). It aims to (1) identify conflicting narratives and their main components and (2) reveal different models of sovereignty on the level of EU member states that have forged an EU solidarity narrative. This article chooses to explore a period of three years $-\mathbf{2 0 1 7 - 2 0 2 0}$.

The article seeks answers the following questions: what idea of sovereignty has been projected to the public in selected European countries and the EU? What model, functional limits and narratives of sovereignty do the actors construct? The first part of this article summarises the theoretical approach and method. It further establishes different categories of sovereignty. The second part examines these categories and their use by different EU actors, such as Juncker, Borrell and Macron (all prominent advocates of the concept of EU sovereignty) vis-à-vis right-wing parties in France as well as the Hungarian and Polish Governments.

\section{Literature and theoretical approach}

A considerable body of literature has addressed a variety of different concepts of sovereignty (Krasner, 1999; Bartelson, 1995; Walker, 2006; Saurugger, 2013). However, there are, so far, no dedicated studies to the recently emerging concept of EU sovereignty (as a unit) or its perception and acceptance in different EU member states. Existing research on EU sovereignty does not deal with the concept of sovereignty per se but 
addresses elements of it, for example, sovereignty's security, defence and economic functions (Cafrun \& Kirkham, 2019; Yakoviyk, 2020).

This research into the concept of EU sovereignty draws on the concept of strategic narratives (Miskimmon, O'Louglin an Roselle, 2013) to analyse its perceptions in different member states. It is important to understand the meaning of a concept, and how it is projected by different actors, which conditions shape the perception of the concept, its expectations together with elements of the narrative that cause conflict. Strategic narrative analysis enables the research methodologically because strategic narratives are a tool for political actors to change the discursive environment in which they operate, manage expectations and extend their influence. These are narratives about both states and the system itself, and about both "who we are" and "what kind of order we want" (Miskimmon, O’Louglin an Roselle, 2013, p. 3). Strategic narratives emerge and are disseminated and reciprocated through the narrative cycle of formation, projection and reception (Miskimmon, O'Louglin an Roselle, 2013, p. 3, 7). I argue that narratives form through the differing concepts of sovereignty, are projected in public communication and the media and received in the general public in different MS, or reciprocally between the different actors involved in forming competing conceptualisations of sovereignty.

I further use discourse analysis as a complementary methodological strategy by focusing on content, participants and context (van Dijk, 2001). Moira Chimombo and Robert Roseberry (1998, p. 9) define discourse as a process of communicative action, the material expression of which takes the form of a text. In this study, there is important content that is defined through the theme (what is a discourse about?) that is developed in discursive texts (speeches and written texts). Discourse analysis looks at what meanings actors give to words.

In examining the expressions of sovereignty, this paper distinguishes among three broad categories: (1) self-identification with a community; (2) unity and purpose; and (3) sovereign and the principle of self-determination. These categories are drawn from the relevant literature on political theory and philosophy, and specifically discussions of sovereignty as developed by Paul Kahn, Bert van Roermund and Martin Loughlin. While these authors usually choose to focus on one of the categories, this article argues that a unidimensional perspective fails to acknowledge the complexity of the concept of sovereignty. This article proposes, instead, to examine sovereignty by means of exploring all three categories in conjunction with each other to grasp the complex nature of the concept of sovereignty in a comprehensive manner.

a) Sovereignty and self-identification with a community: Identification with a particular community is a key element in the perception of sovereignty and the definition of its functional limits. The main question is "who are we?" when identifying elements of the self-identification with a community. To identify with a community is to realise that an individual is a part of its values and goals. Khan distinguishes two types of identification (Kahn, 2004, p. 260): Firstly, selfidentification with a community takes place through the prism of the customs, revolution, history and traditions of a given community - and how such communities tell stories about the Self. Such self-identification is equally crucial when it comes to the establishment of national communities and elements of how people identify with a national community to bestow sovereignty onto national governance processes. Sovereignty becomes a means by which destiny, power and authority interlink. Secondly, the identification with a community takes place 
through the prism of international law by which sovereignty is a functioning mechanism of how international law can enforce legislation in sovereign states and by which individuals might be able to identify not only through the nation-state but through the recognition by other actors.

b) Sovereignty, unity and purpose: Unity is a function of self-awareness (Roermund, 2006, p. 44, 45), created by conscious individuals who identify with a particular community and a shared sense of will and objectives. According to Bert Van Roermund (2006, pp. 44-45) "shared intentions are mutual responsiveness, commitment to joint activity, commitment to mutual support in the process of that joint activity, legislative activity. [...] the agents involved in shared intentional action give shape to that unity". Such shared processes enable unity and purpose through time - which also introduces an element of temporality in the forging process of a community's sovereignty (see also Heinrichs in this Special Issue).

c) Sovereign and the principle of self-determination: First of all, in the traditional sense, the function of the sovereign is based on authority and power. Also, a sovereign is the one who makes the decisions (Schmitt, 2005). People are the product of their own decisions (Kahn, 2011, p. 68), which also underlies rational sensemaking processes. In a representative democracy, the people give decisionmaking power and responsibility to their representatives. In such cases, a background of loyalty to a person, institution or other governance entity creates the enabling logic of sovereignty through representation. Public power itself (and authority) is based on opinion and belief (Loughlin, 2006, p. 63) that such public power is legitimate. Theoretically, citizens can be involved in discussions and deliberations, and express their positions during elections, plebiscites and protest, which is also how sovereignty can be challenged.

\section{Methodological approach}

This paper draws on a qualitative content analysis of political texts. Actors create and transmit discourse and contexts enable discourses. In this paper, the ideological content of texts is important. I apply the three categories established above and from the literature on sovereignty as indicators for coding texts. I thus specifically examine how actors understand the notion of community and self-identification; what unity means and how actors define the functional purpose; who actors define as the authority and the sovereign and who has the right to decide and self-determination. The content of these categories shows us what idea is being disseminated and what direction is being chosen and what model of sovereignty actors create and seek to project.

I focus on French President Emmanuel Macron, the EU's High Representative Joesp Borrell, former European Commssion president Jean-Claude Juncker, and political figures from EU member states - Viktor Orbán (Prime Minister of Hungary), Marine Le Pen (President of the National Rally). All have recently communicated different conceptions of sovereignty in the context of the EU and national contexts. Their function as political leaders also give them an opportunity to impact public opinion significantly. This study finds that all these actors have proposed different concepts of sovereignty, all of which serve different strategic functions. As mentioned above, Emmanuel Macron was one of the first to raise and promote the idea of an EU sovereignty with the support of Jean-Claude Juncker (Juncker, 2018) and Joesp Borrell (Borrell, 2020) and, therefore, fostering a more EU-wide institutionalisation of the recently-introduced concept of EU 
sovereignty. In stark contrast to an idea of EU sovereignty, the ruling parties in Poland and Hungary and their political leaders, as well as The National Rally in France build alternative narratives around the concept of sovereignty and seek to counter the concept of EU sovereignty. This links to Popivanov's paper in this Special Issue in which he reflects different notions of the tempo-spatial narrative sensemaking processes of the EU and Europe.

Thus, I will observe three narratives on sovereignty and solidarity in the EU, broadly represented by Macron and two EU leaders vis-à-vis the (far)-right discourses in three member states (France, Hungary and Poland). I draw on different data for the analysis of each group (see Table 1) and focus on flagship texts that outline narratives of sovereignty particularly explicitly. Regarding EU sovereignty, the documents were selected on the basis of their relevance, circumstances and time sequence from 2017 to 2020. In the case of MS sovereignty, national websites (in English and Polish language) are examined, where the reaction to EU policies is most visible. Marine le Pen's presidential election program was also chosen, expressing her views on the EU and the nation-state sovereignty.

Table 1: Sample for observation

\begin{tabular}{|c|c|}
\hline EU sovereignty & Nationalist/Member States sovereignty \\
\hline $\begin{array}{l}\text { - "Initiative for Europe: A sovereign, united, } \\
\text { democratic Europe" by Emmanuel } \\
\text { Macron } \\
\text { - "State of the Union 2018: The Hour of } \\
\text { European Sovereignty" by Jean-Claude } \\
\text { Juncker } \\
\text { - policy brief "Strategic sovereignty: How } \\
\text { Europe can regain the capacity to act" } \\
\text { - policy brief "The post-coronavirus world is } \\
\text { already here" by Joesp Borrell } \\
\text { - analytical articles in media, especially } \\
\text { Macron's visions }\end{array}$ & 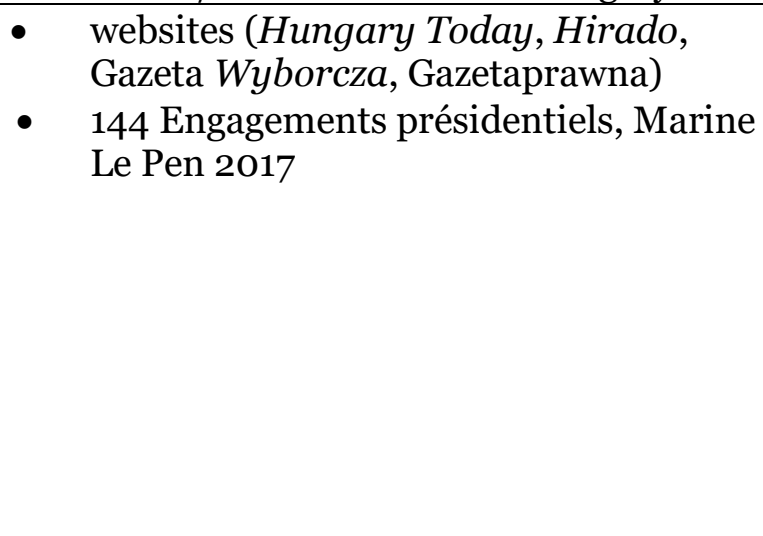 \\
\hline
\end{tabular}

\section{The discourse of sovereignty}

In this section, I will analyse the EU-centric concept of sovereignty vis-a-vis nationalist conceptions of sovereignty.

\section{EU sovereignty}

As mentioned above in 2017, French President Emmanuel Macron proposed that Europe return to Schuman's idea of a united Europe by announcing "six keys to European sovereignty" (Macron, 2017), namely: defence, migration, Africa and the Mediterranean region, ecological and food sovereignty, digital, economic and monetary power as a starting point for the concept of an EU-centric sovereignty.

\section{Self-identification}

According to Macron, the community already exists in the form of the member states and their citizens. The community is built through a variety of components: democracy, sovereignty, identity, but above all, the community is bound by the balance of values; the 
relationship with freedom, human rights and justice (Macron, 2017, p. 4). The identification through these values becomes an important factor in maintaining a united community and they require an identification with the processes underlying such values.

While Macron (2018) considers that there is a "civil war for European sovereignty", fought over different intentions, fears and imaginations of what Europe is and means he cocreates the possibility of a founding narrative event - despite questions over when the concept of European solidarity truly started and what such a civil war would be fought over. Macron crafts a narrative that seeks to reinvigorate the discussions on European solidarity and links it to the unified, value-based community. But as it is unclear as to when the historical narrative emerged, it also becomes difficult to forge a historical narrative that can seek to bind the community together. Historical experiences and traumas of individual nations/states are not reflected due to lack of process of such shared experiences.

\section{Unity and purpose}

According to Macron, solidarity must exist on the level of values and in praxis: "In addition to these six battles for sovereignty, it is the battle for unity I want to lead. We will never have a strong, sovereign Europe if it is not united and coherent within itself" (Macron, 2017, p.14). For Macron, unity requires, first of all, the de-territorialisation of member states, i.e. the abolition of physical borders between states and a fusion of cultural, economic and political borders: "we can no longer choose to turn inwards within national borders [...] So instead of concentrating all of our energy on our internal divisions, [...] we must instead consider how to make a strong Europe" (Macron, 2017, pp. 3, 4.). However, the de-terroritorialisation of member states ends with the territorialisation of the whole. The union establishes itself against its external borders to exercise its sovereignty, at which point the friend-enemy dialectic emerges in Macron's sensemaking. Macron speaks of potential enemies beyond the border, while inside "we" are still trying to create unity. The "enemy" threatens the existence of the community and as such is an essential part of Macron's sovereignty narrative. In Macron's case, the "enemy" is China, the United States and Russia. Friends share responsibilities and identify with other members for a common purpose. Friends include African, Mediterranean (Juncker, 2018), British and Norwegian states. Therefore, it can be said that the concept of sovereignty proposed by Macron has the features of a modern (imperial) sovereignty, where a clear distinction is made between what is outside (not Europe) and what is inside (Europe); he aims to define territory and restore the dialectic of friend and enemy.

\section{Sovereign and the principle of self-determination}

In the classical interpretation of sovereignty, the sovereign is the one who makes decisions for the people and in a modern democracy, the people are the sovereign. They have the right to self-determination and the right to choose to whom to delegate power and decision-making. Proponents of EU sovereignty (Borrell, Macron) emphasise that the right to self-determination should belong to EU citizens who delegate decision-making power to representatives in the European Parliament. However, the EU has other decision-making bodies (European Commission, European Council, Council of the European Union) that could equally function as potential sovereigns presiding over the unity of the whole. This raises problems, both ideologically and practically. Ideologically, or rather democratically, decision-making shifts to different institutions, even to those that people did not elect. In practice, the decision-making at the EU level is lengthy and 
may hamper the ability of the - undefined - sovereign to act, even in times of crisis. Certainly, Macron emphasises that the EU is an overly bureaucratic and technical organisation, unable to take effective and speedy decisions (2017, p. 4). However, he argues that as a result, the EU is losing authority and loyalty among its citizens. To solve this problem, Macron proposes reforms to how the EU functions, for example, through its governance mechanisms, including a need for centralisation and more decision-making at the EU level. Examples, for Macron, include setting criteria that gradually bring tax models closer together, cemented by culture and knowledge (Macron, 2017, p. 15, 16) and the establishment of a European military force with a single European doctrine and budget - all of which reflect elements of the six key concepts he considers at the core of an EUcentric approach to sovereignty.

Macron's narrative of European sovereignty, becomes a complexio oppositorum, where harmony between seemingly incompatible things is sought, such as "sovereignty in sovereignty" (sovereign states in sovereign Europe). Macron proposes a modernist model of sovereignty, which also means a step away from the past and, crucially, past models of sovereignty governance. In this model, sovereignty leaves the confines of the Westphalian state towards a supra-sovereign entity: The European Union. The proposed creation of a sovereign European Republic is based on the narrative that action on a national level faces too many challenges in our modern times and is ill-equipped to deal with global crises, such as the global pandemic. As a result, Macron suggests that it is necessary to restore the unity of Europe, which is based on republican values: human and civil rights, freedom, justice and the ideal of a republic in which citizens are sovereign. While a more general consensus exists among key proponents, other actors, such as Juncker, propose that an EU-centric approach to sovereignty does not replace national sovereignties (Juncker, 2018). Such friction shows that even a more coherent understanding of an EU-centric narrative of EU sovereignty means that more detailed formulations are far from settled.

\section{The state and the national(ist) narrative of sovereignty}

This section will look at the concept of sovereignty of the French Opposition National Front and its leader Marine Le Pen, the Hungarian Prime Minister Viktor Orbán and the ruling political party in Poland (PiS). The attitude of PiS differs little from that of the Hungarian administration; however, Poles are more enthusiastically supportive of Christian values (Duda, 2018).

\section{Community and identification}

In the nationalist and nation-centric narrative of sovereignty, the community is bound through past narratives of culture, shared memory and customs. The narrative projected by the National Front in France is closely linked to the French Revolution, which is understood to have established the French Republic and the sovereignty of the people. The identification with the community takes place through the revolution as an inherited historical narrative, a form of customary knowledge (Lyotard, 1979, p. 38) making it inaccessible to those outside of that custom. In the narrative of Front National that means the community cannot include foreigners, immigrants or non-French nationals (Le Pen, 2017) because they lack participatory identification with such a historical narrative and can noto partake in the process of historical identification.

Similar stories prevail in Hungary and Poland. The path of formation of both communities was marked by many wars and dependencies. The closest shared experience is the 
establishment of communism in both states and the narrative of sovereignty for both states enjoyed a revival with their independence in 1989. These communities still have vivid memories of years of oppression and are therefore particularly sensitive. At the same time, the far-right creates a narrative of new and supposedly 'external' enemies, mostly in the form immigrants. The Hungarian far-right government seeks to strengthen the perception of the Other as an enemy, while internal enemies include all federalists seeking to turn the EU into an institution where decisions are taken from above.

\section{Unity and purpose.}

In this narrative, unity must remain within the nation. It is shared by nations with other members of the EU community when needed, such as in the fight against terrorism or cooperation on migration. In 2017, during the presidential election, Le Pen (2017) stated that France should reduce immigration to zero, fight multiculturalism, return the French sovereignty that the European Commission had "appropriated" and pursue a Europe of independent nations (Le Pen, 2017). The vision of sovereignty is shared by the Hungarian (Székely, 2017a; 2017b) and Polish (Than, Szakacs \& Stonestreet, 2018) administrations. Likewise, Hungary and Poland foster a narrative in which they do not intend to change the boundaries of the sovereign nation and not expand a territorially nation-centric narrative of sovereignty.

\section{The principle of self-determination and sovereign.}

In this narrative, decision-making belongs to the nation and the sovereign is the nation. Orbán (2019) says: "every nation and Member State has the right to decide on how to organise its life in its own country" (Herszenhorn, 2018). The people are the hero of this narrative, legitimising power and giving their leaders the right to act. This part of the narrative is also related to the narrative about the autocracy of EU institutions (especially the European Commission) and their inability to act promptly, which also translates into questions on the legitimacy of the EC's decision-making power. In this narrative, the European Commission should be "a simple technical secretariat" that serves the European Council (Marlowe, 2019) instead.

In summary, the narrative of national(ist) and nation-centric sovereignty is deeply rooted in historical narratives, which underline its exclusionary nature. It relates to the expectation that people can live in a Europe of nation-states and negotiate and share sovereignty only when it serves a strategic purpose. In this narrative, the connection is created between the past and expectations that could be broken by promoters of EU sovereignty end centralisation. 
Table 2: Summary of different discursive representations of sovereignty in the dataset

\begin{tabular}{|c|c|c|}
\hline $\begin{array}{l}\text { Perception of } \\
\text { sovereignty } \\
\text { (formation and } \\
\text { reception) }\end{array}$ & EU sovereignty & $\begin{array}{l}\text { National(ist) and nation- } \\
\text { centric sovereignty }\end{array}$ \\
\hline $\begin{array}{l}\text { Self-identification with a } \\
\text { particular community } \\
\text { (who are we?) }\end{array}$ & $\begin{array}{l}\text { - ES citizens made up of member } \\
\text { states' citizens } \\
\text { - Nations lose relevance. } \\
\text { - Community bound by values } \\
\text { including democracy, identity }\end{array}$ & $\begin{array}{l}\text { - } \text { Community as a nation } \\
\text { - Common past narratives } \\
\text { through culture, revolutions } \\
\text { and traumas } \\
\text { - Community is exclusive }\end{array}$ \\
\hline $\begin{array}{l}\text { Unity and purpose } \\
\text { (what order do we want?) }\end{array}$ & $\begin{array}{l}\text { - Europe united and coherent within } \\
\text { itself } \\
\text { - De-territorialisation (in cultural, } \\
\text { economic and political level) of } \\
\text { member states } \\
\text { - In-territorialisation of the whole } \\
\text { union } \\
\text { - Identification of friend (African, } \\
\text { Mediterranean, British and } \\
\text { Norwegian states) and enemy } \\
\text { (China, US, Russia) dialectic } \\
\text { - European Republic } \\
\text { - member states sovereignty remains } \\
\text { only as a symbol }\end{array}$ & 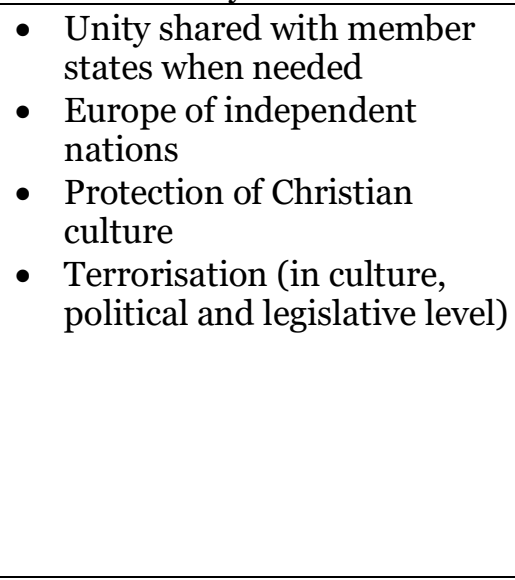 \\
\hline $\begin{array}{l}\text { Sovereign and the } \\
\text { principle of self- } \\
\text { determination (who } \\
\text { decides?) }\end{array}$ & 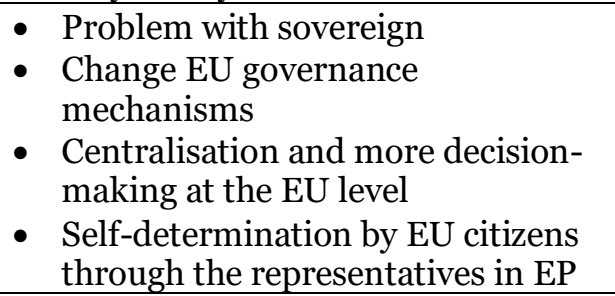 & $\begin{array}{l}\text { - Decision-making belongs to } \\
\text { the nation } \\
\text { - Sovereign-people of states } \\
\text { giving their leaders the right } \\
\text { to act }\end{array}$ \\
\hline
\end{tabular}

\section{Interpretation and Conclusions}

The concept proposed by proponents of EU-centric sovereignty is based on elements of traditionally perceived sovereignty: territory, community, us-them dialectics, establishment "through revolution", however, conceptually the boundaries of such sovereignty and the 'glue' of such community changes (for a summary of positions see table 2). The aim is to give more shaping power to the EU institutions and centralise decision-making in defence, health care, tax system, ecological, digital and the social spheres. Such authority based on public opinion should be acquired by the EP, reflecting the will of the European people. This narrative of sovereignty does not change its traditional content; it only changes the object, moving from the state to the supra-state. As the EU faces multiple challenge, it is trying to establish and recognise its sovereignty, which also translates into a new image of power. The narrative intends to create the European Republic after a successful "revolution”.

Proponents of a nationalistic, nation-centric sovereignty equally rely on their history and the narrative of the revolution and the traditions of a Christian Europe. The far-right creates a narrative around the community that has a special connection between the past and their objectives. In this narrative sovereignty 'belongs' to the (territorially bound) state, which is established by the common will of the people, and this can neither be shared nor relinquished. The aim is a union of nation-states, where the main decisions are made by states, rather than the European Council and the EP or the main institutions of the EU. 
In this situation, the ambitions of the two groups are different. In practice, nations still exist but in theory, only EU citizens are to remain. Viewed through the prism of the strategic narrative theory, the formation of the concept of sovereignty takes place through its idea projection and perception. While the concept of sovereignty can divide or can be a means to forge unity among community members - at the expense of those that sovereignty excludes - its application and narration is very difficult and complex. I have shown that two fundamentally different narratives on sovereignty of the EU or within Europe correspond to strategic objectives and historical narratives that equally 'write' the role of the people and the state. Looking forward, the EU will have to engage in conversations around different models of sovereignty, while granting sufficient space to engaging with 'alternative' narratives, however uncomfortable or contradictory they may be.

\section{References}

Bodin, J. (1992). On Sovereignty. New York: Cambridge University Press.

Borrell, J. (2020,). The post-coronavirus world is already here. https://www.ecfr.eu/publications/summary/the post coronavirus world is al ready here

Cafruny, A., Kirkham, K. (2019). EU 'Sovereignty’ in Global Governance. In Grigoryev. L. (ed.) Global Governance in Transformation. Springer Nature, 89-104.

Chimombo, M. P. F., \& Roseberry, R. L. (1998). The power of discourse. Lawrence Erlbaum Associates Publishers

Duda, A. Bruksela i Europa mają inną wizję państwa niż my. (2018, November 8), https://wyborcza.pl/7,75398,24142549, duda-o-ue-bruksela-i-europa-majazupelnie-inna-wizje-systemu.html?disableRedirects=true

Europe's civil war of sovereignty is tearing its soul apart. The Economist. (2018, July 18), https://www.economist.com/open-future/2018/07/18/europes-civil-war-ofsovereignty-is-tearing-its-soul-apart

Herszenhorn, D. M. (2018, September 11). Rumble with Hungary exposes EU divisions. Politico. https://www.politico.eu/article/state-of-disunion/

Jakoviuk, I. V. (2020). Strategic autonomy of the European Union: on the way to „European sovereignty“ in defense. Problem of Legality, 149, 224-242.

Juncker, J. C. (2018). State of the Union 2018: The Hour of European Sovereignty. Strasbourg.

Kahn, P. W. (2004). The Question of Sovereignty, Stanford Journal of International Law, 40:259, 259-282.

Kahn, P. W. (2011). Political Theology: Four New Chapters on the Concept of Sovereignty. Columbia University Press. New York.

Krasner, S, D. (1999). Sovereignty: Organized Hypocrisy. Princeton University Press.

Le Pen, M. (2017). 144 Engagements présidentiels Marine 2017. https://rassemblementnational.fr/pdf/144-engagements.pdf 
Leonard, M. \& Shapiro, J. (2019). Strategic sovereignty: How Europe can regain the capacity to act. European Council on Foreign Relations.

https://ecfr.eu/publication/strategic sovereignty how europe can regain the capacity to act/

Leonard, M. \& Shapiro, J. (2020). Sovereign Europe, dangerous world: Five agendas to protect Europe's capacity to act. Celis Institute. https://www.celis.institute/celisnews/sovereign-europe-dangerous-world-five-agendas-to-protect-europescapacity-to-act-european-council-on-foreign-relations/

Loughlin, M. (2006). Ten Tenets of Sovereignty. In N. Walker (Ed.) Sovereignty in Transition (p.p. 55-86). Oxford and Portland, Oregon: Hart Publishing.

Lyotard, J. F. (1979). La Condition postmoderne. Les Éditions de Minuit: Paris.

Macron, E. (2017). Initiative for Europe: A sovereign, united, democratic Europe,

Marlowe, L. (2019). Marine Le Pen: The EU is dead. Long live Europe, https://www.irishtimes.com/news/world/europe/marine-le-pen-the-eu-is-deadlong-live-europe-1.3801809

Miskimmon, A., O’Loughlin, B., \& Roselle, L. (2013). Forging the World: Strategic Narratives and International Relations, London: New Political Communication Unit / Centre for European Politics, Royal Holloway University of London.

Roermund, B. (2006). Sovereignty: Unpopular and Popular. In N. Walker (Ed.) Sovereignty in Transition (33-54). Oxford and Portland, Oregon: Hart Publishing.

Schmitt, C. (2005). Political Theology: Four Chapters on the Concept of Sovereignty. The University of Chicago Press.

Székely, T. (2017a, b,), Hungary PM Viktor Orbán: “Multiculturalism Has Failed In Europe”, The Issue Of Migrants Is Therefore An Issue Of Identity As Well As Sovereignty", https://hungarytoday.hu/migrants-issue-identity-sovereigntyhungarian-orban-speech-full-20779/

Than, S., Szakacs, G., \& Stonestreet, J. (2018, April 6) Europe should be based on strong nation states. https://fr.reuters.com/article/us-hungary-polandsmolensk/europe-should-be-based-on-strong-nation-states-polands-kaczynskiidUSKCN1HD187

Van Dijk, T. A. (2001). Critical discourse analysis. In D. Tannen (Eds.), Handbook of discourse analysis. Oxford: Blackwell.

Walker, N. (2006). Sovereignty in Transition. Oxford and Portland, Oregon, Hart Publishing. 